\title{
EFFECT OF CORPORATE GOVERNANCE AND PROFITABILITY ON TAX AVOIDANCE (Empirical Study of Sharia Banking Companies Listed on the Indonesia Stock Exchange 2012-2016)
}

\author{
Hasian Purba \\ Accounting Study Program, Faculty of Economics and Business, \\ Universitas Mercu Buana
}

\begin{abstract}
The objectives of this study are as follows: 1) Finding empirical evidence regarding the influence of the independent board of commissioners on tax avoidance; 2) Finding empirical evidence regarding the influence of the audit committee on tax avoidance; 3) Finding empirical evidence regarding the effect of audit quality on tax avoidance; and 4) Finding empirical evidence regarding the effect of profitability on tax avoidance. This type of research used in this study is casual associative research (causal associative research). The population in this study is Islamic commercial banks listing on the Indonesia Stock Exchange for the period 2012-2016. Sample selection with purposive sampling method. The analytical method used to test hypotheses is the multiple regression test. The results showed that: 1) The independent board commissioner variable had no effect on tax avoidance; 2) The audit committee variable has no effect on tax avoidance; 3) The audit quality variable influences tax avoidance; and 4) Profitability variables affect tax avoidance.
\end{abstract}

Keyword : Corporate Governance, Profitability, Tax Avoidance

DOI: $10.7176 /$ RJFA/10-18-17

Publication date:September $30^{\text {th }} 2019$

\section{INTRODUCTION}

Tax is the biggest source of state revenue. The tax collected by the State functions as a source of funds intended for financing government expenditure and functions as a tool to regulate and implement policies in the social and economic fields and is used for the greatest prosperity of the people. Therefore, corporate and individual taxpayers are expected to be obedient in carrying out their tax obligations voluntarily and in compliance with tax regulations. Non-compliance of taxpayers can cause disruption of State finances. One way of non-compliance is done by way of tax avoidance, which is legal tax avoidance that does not violate tax regulations by taxpayers by reducing the amount of tax owed by looking for weaknesses (Hutagoal, 2007 in Dewi \& Jati, 2014).

In an effort to reduce the tax burden the management can do a variety of ways such as tax avoidance (tax avoidance). Tax avoidance (tax avoidance) is an aggressive tax strategy undertaken by companies in order to minimize the tax burden, so this activity raises risks for companies, including fines and bad reputation of the company in the eyes of the public (Ayu \& Lulus, 2012). The tax avoidance that is done is said to be not in conflict with the taxation regulations because it is considered that practices related to tax avoidance make more use of the gaps in the taxation laws which will affect the state revenue of the tax sector (Mangoting, 1999 in Dewi \& Teak, 2014). However, the practice of tax avoidance cannot always be implemented because taxpayers do not always avoid all elements or facts imposed in taxation (Dewi \& Jati, 2014).

According to Fitri \& Tridahus (2015), the issue of tax avoidance is a complex and unique problem. On the one hand it is permissible but on the other hand avoidance of unwanted taxes. In Indonesia, various regulations have been made to prevent tax avoidance. One of them is related to transfer pricing, which is about the principle of fairness and custom in transactions between taxpayers and parties who have a special relationship (Perdirjen No. PER-43 / PJ / 2010, 2010).

Cases involving tax avoidance that have been carried out by well-known companies such as Apple Inc. (2012) which have hidden income money of US \$ 11 billion in countries that have received tax breaks include Virginia Island, Ireland and Luxembourg. So the tax paid is small. Starbuck (2012) who made financial statements as if they were at a loss by paying royalties on designs, recipes and logos to branches in the Netherlands. Paying debt interest is very high, where the debt was apparently used for coffee shop expansion in other countries. Buy raw materials from branches in Switzerland. Although shipping goods directly from the producer country and does not enter Switzerland. Internet search engine company in the United States (2011) The company posted revenue in the UK of 398 million pounds in 2011, but only paid a tax of 6 million pounds. The profits from the British branch company were transferred to branches in Ireland, the Netherlands and Bermuda. Bermuda country is a tax haven country that does not collect corporate income tax. And other cases that make state revenue in the taxation sector decrease (Merdeka.com). 
In this era of globalization, many companies are implementing corporate governance practices to minimize business risks that may occur. Corporate governance is corporate governance that explains the relationships between various participants in the company that determine the direction of company performance. This corporate governance problem began to emerge in Indonesia after the financial crisis in 1998. According to Fitri \& Tridahus (2015), there was a survey which showed that Indonesia had occupied the lowest position in 2002 in terms of audit and compliance, accountability to shareholders, disclosure standards and transparency and the role of directors. Therefore, in Indonesia itself a National Committee on Governance Policy has been formed which produces a guideline for Good Corporate Governance. In Indonesia, investors and the government paid significant attention to the practice of corporate governance because since 1998 when Indonesia experienced a prolonged crisis, the process of improvement in Indonesia was felt very long due to the weak corporate governance implemented by companies in Indonesia.

Corporate governance is a system or mechanism that regulates and controls companies to create added value for all stockholders. The company is one of the taxpayers while corporate governance explains the relationships between various participants in the company that determine the direction of corporate performance, so that with corporate governance has a role in decision making, including in decisions in terms of meeting tax obligations, but on the other hand tax planning depends on the dynamics of corporate governance in a company (Friese, Link and Mayer, 2006 in Diantari \& Ulupui, 2016).

The birth of Good Corporate Governace (GCG) in Islamic banks began with the issuance of Bank Indonesia Regulation (PBI) which emphasized the need for GCG implementation in banks, namely PBI No. 8/4 / PBI / 2006 concerning GCG Implementation for Commercial Banks. This PBI also applies to Islamic banks, which means that Islamic banks are also required to apply GCG principles in the operation of their activities. But since 2010, PBI No. 8/4 / PBI / 2006 is no longer valid for Islamic banks. Instead, PBI No. was issued. 11/33 / PBI / 2009 concerning GCG Implementation for Sharia Commercial Banks and Sharia Business Units. This replacement is due to the fact that GCG that will be applied in Islamic banking must be in accordance with Islamic principles. The implementation of GCG that meets the sharia principles as intended in this PBI is reflected in the implementation of the duties and responsibilities of the sharia supervisory board in managing sharia banking activities (Lidia, et al, 2016).

The role of corporate governance has been far applied in Islamic teachings. The principles of Good Corporate Governance which consist of transparency, accountability, responsibility, professional and fairness have been contained in sharia values which intensely consist of Adaalatun (justice ), tawazun (balance), mas'uliyah (accountability), morality (moral), shiddiq (honesty), amanah (fulfillment of trust), fathanah (intelligence), tabligh (transparency / openness), hurriyah (independence and responsible freedom), ihsan (professional), wasathan (fairness), ghirah (militancy syari'ah), idarah (management), khilafah (leadership), aqidah (faith), ijabiyah (positive thinking), raqabah (supervision), qira'ah and ishlah (organizations that continue to learn and always make improvements) and sharia values are included in the principles of sharia (Rifka in Lidia, et al, 2016).

Good corporate governance can affect tax avoidance or tax avoidance. This was proven empirically by previous researchers such as research conducted by Syeldila \& Niki (2015) of manufacturing companies listed on the Indonesia Stock Exchange in the period 2011-2013, the results of his research showed that the proportion of independent commissioners, audit quality, and audit committee has a negative and significant effect on tax avoidance. According to Arry (2017) in the Influence of Independent Commissioners, Audit Committees, and Audit Quality Against Tax Avoidance, the results of the study show that independent commissioners and audit quality have a positive effect on tax avoidance. Audit committees do not significantly influence tax avoidance.

Profitability is a measurement of a company's performance. Profitability of a company shows the ability of a company to generate profits for a certain period at a certain level of sales, assets and share capital. Profitability consists of several ratios, one of which is return on assets (ROA). ROA serves to measure the effectiveness of a company in the use of its resources. ROA is used because it can provide an adequate measurement of the overall effectiveness of the company and ROA can also take into account profitability.

ROA is a measure of net profits derived from how much the company uses assets. The higher the value of ROA, the higher the company's profit so the better the asset management of a company. The higher the value of ROA, the greater the profit earned by the company. Agency theory will spur agents to increase company profits. When the profits obtained increase, the amount of income tax will increase in accordance with the increase in corporate profits so that the tendency to do tax avoidance by the company will increase. Research related to profitability from Kurniasih and Maria (2013), Maharani \& Suardana (2014) shows that ROA has a negative effect on tax avoidance. Related research was also conducted by Dewinta \& Setiawan (2016) which showed ROA has a positive effect on tax avoidance.

Researchers are motivated to conduct research in the sharia banking industry on the grounds that in the sharia banking industry in each of its operational activities such as depositing funds and or financing business activities, or other activities must be declared in accordance with sharia. In accordance with sharia referred to here that in operational activities of sharia commercial banks must base on sharia values. In these sharia values the principles of good corporate governance are contained. So that the sharia values that are incorporated into sharia principles are expected to be able to maintain the management of sharia economic and financial institutions in a professional manner and to maintain economic, business and social interactions in order to run in accordance with applicable 
rules and best practice (Rifka in Lidia, et al, 2016). In other words, Islamic commercial banks will become more effective in implementing corporate governance. The implementation of effective corporate governance is expected to be able to bridge the back of taxpayer thinking that tax is an obligation not a burden so it can suppress the practice of tax avoidance.

Based on the description above, then in this study the Good Corporate Governance Mechanism variable which is proxy by the independent commissioners, audit committee, audit quality, and profitability variables will be used as independent variables that affect tax avoidance in Islamic Banking companies listed on the Indonesia Stock Exchange In 2012-2016, the authors were interested in conducting a study entitled "The Effect of Corporate Governance and Profitability on Tax Avoidance (Empirical Study of Sharia Banking Companies Listed on the Indonesia Stock Exchange in 2012-2016)".

\section{LITERATURE REVIEW}

Agency Theory

Jensen and Meckling (1976) state that an agency relationship is a contract between a manager (agent) and an investor (principal). There is a conflict of interest between the owner and agent because the possibility of the agent acting is not in accordance with the interests of the principal, thereby triggering agency costs. Conflict in agency theory is usually caused by decision makers who do not participate in taking risks as a result of decision making mistakes. According to decision makers, the risk should be borne by the shareholders. This is what causes the asynchronous between the decision maker (manager) with the shareholders. Conflicts between shareholders and company management can be minimized in a way, managers must run the company in accordance with the interests of shareholders as well as in making decisions by managers must be adjusted to the interests of shareholders (Wahyuni, 2013).

\section{Stakeholders Theory}

According to Clarkson (1995) in Fauzan (2013), stakeholders are divided into two groups, namely primary and secondary. Primary stakeholders are groups of stakeholders who do not take part or participate in the operations of a company. Secondary stakeholders are groups of stakeholders who influence and are influenced by the company, but are not involved and are not so important for the survival of the company.

Stakeholder theory is a theory which states that a company is an entity that not only operates for its own interests, but must provide benefits to all its stakeholders, because the survival of a company is supported by stakeholders (Ghazali and Chariri, 2007). Shareholders, creditors, consumers, suppliers, governments, the public, analysts, and other parties are stakeholder groups that are considered by the company to disclose or not disclose information in the company's financial statements. All stakeholders have the right to obtain information about company activities.

\section{Good Corporate Governance (GCG)}

According to Keasy, Corporate governance is a structure, process, culture and system for creating successful operational conditions for an organization (Sunarto in Syukri and Chenny, 2018). Koesnohadi (in Syukri and Chenny, 2018) said that "Good Corporate Governance is a relationship between stakeholders that is used to determine and control the strategic direction and performance of the organization".

According to Tangkilisan (2003, in Angrum, 2016) good corporate governance (GCG) is a system and structure for managing companies with the aim of increasing company value and allocating it to various interested parties such as creditors, suppliers, business associations, consumers, workers, government and wide community. The same thing also expressed by Sutedi (2011) GCG by definition is a system that regulates and controls the company to create added value for all shareholders (stakeholders). GCG can only be created if there is a balance between the interests of all parties with the interests of the company to achieve company goals (Khairandy and Malik, 2007 in Angrum, 2016).

From the above understanding it can be concluded that Good Corporate Governance is a system of corporate governance in order to be better and can increase Company Value by promoting fairness for all stakeholders, transparency regarding the condition of the company as part of the external environment. (Haris, 2008 in Syukri and Chenny, 2018)

\section{Corporate Governance Mechanism}

Corporate Governance usually refers to a set of mechanisms that influence the decisions to be taken by managers when there is a separation between ownership and control. Some of these controls lie in the functions of the board of directors, institutional shareholders, and control of market mechanisms (Larcker et al. In Wardhani , 2006 in Syukri and Chenny, 2018). Success or failure of the company will be largely determined by the decisions or strategies taken by the company. The board plays a very significant role even the main role in determining the company's strategy. Indonesia is a country that uses the concept of twotier, where the board consists of the Board of Directors and the Board of Commissioners (Wardhani, 2006 in Syukri and Chenny, 2018).

In addition, Islamic commercial banks need to form sharia supervisory boards in order to purify and adjust various models and instruments of bank finance with sharia provisions (Chapra and Ahmed, 2008 in Syukri and Chenny, 2018). So the corporate governance mechanism that is an indicator of good corporate governance in this study is the proportion of independent commissioners, audit committees, and audit quality.

a. Independent Board of Commissioners 
According to Puspitasari and Ernawati (2010 in Syukri and Chenny, 2018) independent commissioners are members of the board of commissioners who have no financial, management, share ownership and / or family relationship with other members of the board of commissioners, directors and / or controlling shareholders or other relationships who is able to act independently. The board of commissioners plays an important role in corporate governance, because company law concerns the legal affairs and responsibilities of the company to the board of commissioners.

In a company, the board of commissioners represents the main internal mechanism in carrying out the control function of the principal and oversees the opportunist behavior of management. The board of commissioners also acts as a representative of shareholders whose function is to exercise control and provide advice to directors to run GCG. The dual board (two-tier) system is a system used by companies in their internal organizational structures, better known as boards of commissioners and boards of directors.

The proportion of independent commissioners in this study was calculated using the ratio of independent commissioners divided by the total number of all boards of commissioners.

b. Audit Committee

The audit committee is the committee responsible for overseeing external audits and is the main contact between the auditor and the company (Dewi \& Jati, 2014). The existence of an audit committee within a company is expected to be able to provide insight on matters relating to financial policies, accounting, and internal control of a company. In this study the audit committee will be measured using a ratio that is the number of audit committees outside the independent commissioners divided by the number of audit committees in the company.

c. Audit quality

Audit quality is any possibility that can occur when the auditor audits the client's financial statements and finds violations or errors that occur and report them in the audited financial statements (Dewi \& Jati, 2014). Transparency towards shareholders can be achieved by reporting matters related to taxation in the capital market and the meeting of shareholders. Increased transparency towards shareholders in tax matters is increasingly being demanded by public authorities (Sartori, 2010). Because of the assumption of the implications of aggressive tax behavior, their companies take an aggressive position in tax matters and would prevent such actions if they were a year earlier. Therefore, audit quality is measured using a dummy variable of value 1 if the financial statement audit is carried out by The Big Four Public Accounting Firm (KAP) namely Price Water House Cooper-PWC, Deloitte Touche Tohmatsu, KPMG, and Ernst \& Young-E \& Y, and is 0 if the financial statement audit is not carried out by The Big Four Public Accountant Firm (KAP).

\section{Profitability}

Profitability is a measurement of a company's performance. Profitability of a company shows the ability of a company to generate profits for a certain period at a certain level of sales, assets and share capital. Profitability consists of several ratios, one of which is return on assets (ROA). ROA serves to measure the effectiveness of a company in the use of its resources (Siahan, 2004). ROA is used because it can provide an adequate measurement of the overall effectiveness of the company and ROA can also take into account profitability.

ROA is a measure of net profits derived from how much the company uses assets. The higher the value of ROA, the higher the company's profit so the better the asset management of a company. The higher the value of ROA, the greater the profit earned by the company. Agency theory will spur agents to increase company profits. When the profits obtained increase, the amount of income tax will increase in accordance with the increase in corporate profits so that the tendency to do tax avoidance by the company will increase.

Based on Bank Indonesia Circular Letter No.13 / 24 / DPNP dated October 25, 2011 (Hafidz and Safira, 2018). Return On Assets can be calculated using the formula:

$$
R O A=\frac{\text { Profit before tax }}{\text { RAverage Total Assets }}
$$

\section{Tax avoidance}

Tax Avoidane is a business transaction scheme aimed at minimizing the tax burden by utilizing the weaknesses (loophole) of a country's taxation provisions. According to Lim (2011) defines tax avoidance as tax savings that arise by utilizing tax provisions that are done legally to minimize tax obligations.

Tax avoidance (tax avoidance) is an effort to avoid tax that is done legally and safely for taxpayers because it does not conflict with taxation provisions, where the methods and techniques used tend to exploit the weaknesses (gray areas) contained in the laws and regulations taxation itself, to reduce the amount of tax owed (Pohan, 2013).

According to Dyreng et al. (2010) this variable is calculated using the cash effective tax rate (CETR), which is the payment of income tax divided by profit before tax.

\section{Previous Research Review}

Previous research that can support this research is Syeldila \& Niki (2015) in his research entitled "The Effect of Corporate Governance on Tax Avoidance: Empirical Studies in Manufacturing Companies" provides evidence that the proportion of independent commissioners, audit quality, and audit committees has a negative and 
significant influence with respect to tax avoidance, while institutional ownership does not consider taxation determinant in Indonesian manufacturing companies.

Fitri \& Tridahus (2015) in her study entitled "The Influence of Audit Committees, Audit Quality, Institutional Ownership, Company Risk and Return On Assets Against Tax Avoidance" provides empirical evidence that corporate risk and return on assets influence tax avoidance. While the audit committee, audit quality and institutional ownership have no effect on tax avoidance.

Christopher, et all. (2015) in his study entitled "Corporate governance, incentives, and tax avoidance" provides empirical evidence that a positive relationship between board independence and financial sophistication is for a low level of tax avoidance, but a negative relationship for a high level of tax avoidance. These results indicate that these governance attributes have a stronger relationship with more extreme levels of tax avoidance, which are more likely to be symptoms of over-investment and under-investment by managers.

Diantari \& Ulupui (2016) in their study entitled "The Influence of the Audit Committee, the Proportion of Independent Commissioners, and the Proportion of Institutional Ownership on Tax Avoidance" provides evidence that the audit committee and the proportion of independent directors negatively affect tax avoidance, the proportion of institutional ownership has no effect on tax avoidance, and company size as a control variable have a positive effect on tax avoidance.

Arry (2017) in his research entitled "The Effect of Independent Commissioners, Audit Committees, and Audit Quality on Tax Avoidance" provides empirical evidence that independent commissioners and audit quality have a positive effect on tax avoidance, audit committees do not significantly influence tax avoidance Simultaneously independent commissioners, audit committees and audit quality have a significant effect on tax avoidance

\section{Theoretical Thought Framework}

Based on the theoretical basis and some previous research, the framework in this study can be shown by the following picture:

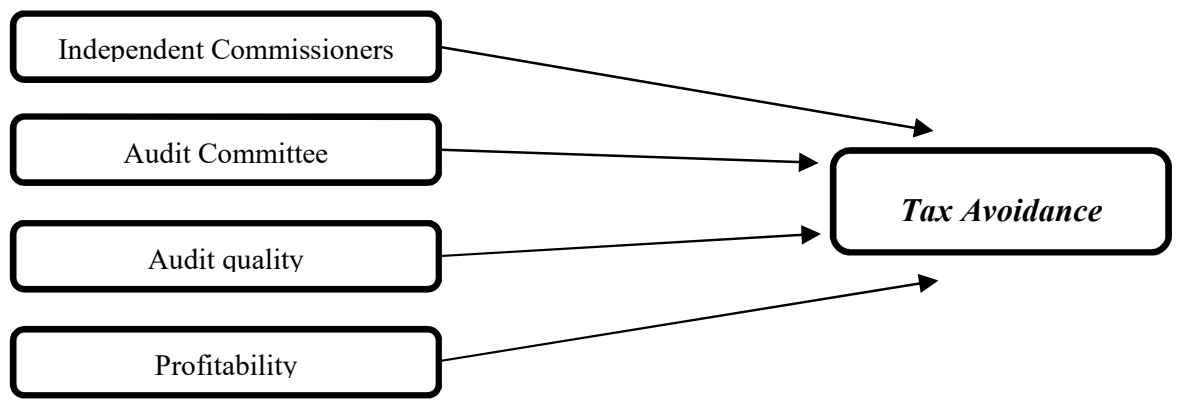

Figure 1.1 Research Model

\section{Research Hypothesis}

From the above thought framework, the researcher draws a hypothesis as follows:

$\mathrm{Ha}_{1}=$ Independent Board of Commissioners effect on Tax Avoidance

$\mathrm{Ha}_{2}=$ Audit Committee effect on Tax Avoidance

$\mathrm{Ha}_{3}=$ Audit quality effect on Tax Avoidance

$\mathrm{Ha}_{4}=$ Profitability effect on Tax Avoidance

.

\section{RESEARCH METHODOLOGY}

\section{Types of research}

This type of research used in this study is casual associative research (causal associative research). According to Sanusi (2011), associative-causal research is research that looks for relationships between two or more variables. The purpose of associative research is to look for relationships between one variable and another.

\section{Operational Definition and Variable Measurement}

The variables used in this study consisted of the dependent variable and the independent variable. Operational research variables can be summarized in table 1.1 . 
Table 1.1 Operationalization of Variables

\begin{tabular}{|c|c|c|c|}
\hline $\begin{array}{c}\text { Variable } \\
\text { Type }\end{array}$ & Operational definition & Measurement & Scale \\
\hline \multicolumn{4}{|l|}{ Dependent } \\
\hline $\begin{array}{l}\text { Tax } \\
\text { Avoidance }\end{array}$ & $\begin{array}{l}\text { Tax avoidance efforts are carried out } \\
\text { legally and safely for taxpayers } \\
\text { because they do not conflict with } \\
\text { taxation provisions, where the } \\
\text { methods and techniques used tend to } \\
\text { exploit the weaknesses (gray area) } \\
\text { contained in the laws and tax } \\
\text { regulations themselves, to reduce the } \\
\text { amount tax owed }\end{array}$ & $\begin{array}{c}\text { Cash Effective Tax Rate } \\
\text { (CETR) }\end{array}$ & Rasio \\
\hline \multicolumn{4}{|l|}{ Independent } \\
\hline $\begin{array}{l}\text { Independent } \\
\text { Board of } \\
\text { Commission } \\
\text { ers }\end{array}$ & $\begin{array}{l}\text { Members of the board of } \\
\text { commissioners who do not have } \\
\text { financial, management, share } \\
\text { ownership and / or family relations } \\
\text { with the controlling shareholder, } \\
\text { members of the board of } \\
\text { commissioners and / or directors (Bank } \\
\text { Indonesia Regulation number } \\
11 / 33 \text { / PBI / 2009) }\end{array}$ & $\begin{array}{l}\text { The number of independent } \\
\text { directors is divided by the } \\
\text { total number of the board of } \\
\text { commissioners }\end{array}$ & Rasio \\
\hline $\begin{array}{l}\text { Audit } \\
\text { Committee }\end{array}$ & $\begin{array}{l}\text { The committee responsible for } \\
\text { overseeing external audits and is the } \\
\text { main contact between the auditor and } \\
\text { the company (Dewi \& Jati, 2014) }\end{array}$ & $\begin{array}{l}\text { The number of Audit } \\
\text { Committees outside the } \\
\text { independent commissioners } \\
\text { is divided by the number of } \\
\text { Audit Committees in the } \\
\text { company }\end{array}$ & Rasio \\
\hline Audit quality & $\begin{array}{l}\text { All possibilities that can occur when } \\
\text { the auditor audits the client's financial } \\
\text { statements and finds violations or } \\
\text { errors that occur and report it in the } \\
\text { audited financial statements (Dewi \& } \\
\text { Jati, 2014) }\end{array}$ & $\begin{array}{l}\text { Value } 1 \text { if the financial } \\
\text { statement audit is carried out } \\
\text { by The Big Four Public } \\
\text { Accounting Firm (KAP) } \\
\text { namely Price Water House } \\
\text { Cooper - PWC, Deloitte } \\
\text { Touche Tohmatsu, KPMG, } \\
\text { and Ernst \& Young - E \& } \\
\text { Y, and value } 0 \text { if the } \\
\text { financial statement audit is } \\
\text { not carried out by the } \\
\text { Accounting Firm Public } \\
\text { (KAP) The Big Four }\end{array}$ & dummy \\
\hline Profitability & $\begin{array}{l}\text { The ability of a company to generate } \\
\text { profits for a certain period at a certain } \\
\text { level of sales, assets and share capital }\end{array}$ & ROA & Rasio \\
\hline
\end{tabular}

\section{Research Population}

The population used in this study is Islamic commercial banks listed on the Indonesia Stock Exchange for the period 2012-2016, which amounted to 12 banks.

\section{Research Samples}

The sample is part of the population used to estimate population characteristics. Data samples were taken using purposive sampling technique, the criteria used are:

1. The company publishes annual reports and financial reports for 5 consecutive years (2012-2016) which can be accessed from the IDX website (www.idx.co.id) or from the company's website.

2. Published audited financial statements for the period 2012-2016

3. Companies that use rupiah value units in their financial statements. 
4. The company did not experience losses during the research year.

5. The company owned data is complete and in accordance with the variables studied.

According to the criteria above, the number of sample companies used were 8 banks for 5 periods namely 2012, 2013, 2014, 2015 and 2016. Then obtained a total sample of 8 banks x 5 periods $=40$ data to be used in this study.

\section{Data collection technique}

Data collection methods in this study are library study methods and documentation methods. Literature study method by studying literature and reviewing a variety of literature literature such as various journals, articles and other literature books that support the research process. While the documentation method is the process of collecting data by recording documents related to this study.

\section{Analysis Method \\ Descriptive statistics}

Descriptive statistics in this study are used to provide a description of the character of the research variable using a frequency distribution table that shows the mode number, the range of scores and the standard of division

\section{Classic assumption test}

This research was conducted with a simple regression analysis. The use of simple regression analysis must be free from testing classic assumptions. For this reason, before a simple regression analysis must be done testing the classic assumptions first. Testing classic assumptions is done using normality test, multicollinearity test, heterokedasticity test and autocorrelation test.

\section{Hypothesis testing}

In this study the authors used four independent variables and one dependent variable. The analytical method used to test hypotheses is the multiple regression method, which is regression used to find out how much influence the independent variable has on the dependent variable. Regression analysis using SPSS software version 22 . The regression equation is as follows: $Y=\alpha+\beta_{1} X_{1}+\beta_{2} X_{2}+\beta_{3} X_{3}+\beta_{4} X_{4}+\varepsilon_{1}$

\section{Where :}

$\mathrm{Y}=$ Tax Avoidance

$\alpha=$ constant or price of $\mathrm{Y}$ if $\mathrm{X}=0$

$\beta=$ number or direction of the regression coefficient, which indicates the number of increase or decrease in the dependent variable based on the independent variable

$\mathrm{X}_{1}=$ Independent Board of Commissioners

$\mathrm{X}_{2}=$ Audit Committee

$\mathrm{X}_{3}=$ Audit quality

$\mathrm{X}_{4}=$ Profitability

$\mathcal{E}=$ error

In this study, the significance level $(\alpha)$ of 0.05 or $5 \%$ was used. To test whether the proposed hypothesis is accepted or rejected, a test of the research variables is tested by simultaneously testing the simultaneous significance test (F statistic test), which intends to explain the effect of the independent variable on the dependent variable. Meanwhile, to test each variable partially, it is carried out by means of an individual parameter significance test (statistical t test) which aims to find out whether the independent variable influences the dependent variable, and which of the dominant variables influences the dependent variable.

\section{Research Data Description}

\section{RESEARCH RESULTS AND DISCUSSION}

Descriptive statistical results about the research variables are presented in table 1.2. From this table we can find information about the average, maximum value, minimum value and standard deviation. 
Table 1.2 Descriptive Statistics Results

\begin{tabular}{|l|c|c|c|c|}
\hline \multicolumn{1}{|c|}{ Variabel } & Min & Max & Mean & $\begin{array}{c}\text { Std. } \\
\text { Deviation }\end{array}$ \\
\hline Independent of Commissioners & 0,33 & 1,00 & 0,64 & 0,143 \\
\hline Audit Committee & 0,25 & 0,83 & 0,54 & 0,171 \\
\hline Audit quality & 0 & 1 & 0,67 & 0,474 \\
\hline Profitability & 0,001 & 0,030 & 0,01 & 0,007 \\
\hline Tax Avoidance & 0 & 1,89 & 0,37 & 0,395 \\
\hline
\end{tabular}

\section{Source: Processed data (2019)}

Based on table 1.2 above, it can be presented descriptive statistical results about the research variables as follows: the independent commissioner variable has an average of 0.64 or $64 \%$. This shows that the independent commissioner variable has fulfilled the requirements determined by the Financial Services Authority Regulation No. 33 / POJK.04 / 2014 that the proportion of independent commissioners must be at least $30 \%$ of the total members of the board of commissioners (OJK 2014). The standard deviation value of the independent commissioner variable is 0.143 , this value indicates the magnitude of increase and decrease in the maximum independent commissioner variable that may occur. The lowest amount is 0.33 or $33 \%$ and the highest number reaches 1.00 or $100 \%$.

The audit committee variable has an average value of 0.54 with a standard deviation of 0.171 . The company that has the smallest audit committee is PT. Bank Muamalat Indonesia Tbk \& PT. BRI Syariah Tbk which is equal to 0.25 . The company that has the largest audit committee is PT. BRI Syariah Tbk which is equal to 0.83 .

The audit quality variable has an average value of 0.67 with a standard deviation of 0.474 . This shows that $67 \%$ of the sample company's financial statements were audited by The Big Four Public Accounting Firm (KAP). The standard deviation value of audit quality variables is 0.474 , this value indicates the magnitude of increase and decrease in maximum audit quality variables that may occur. The lowest value is 0 and the highest value is 1 .

The average value of profitability variables measured by ROA is $0.01 \%$ with a standard deviation value of $0.007 \%$, which means that the financial performance of Islamic commercial banks does not have a large enough variance. Profitability variables range from the lowest value of $0.001 \%$, namely PT. BRI Syariah Tbk up to the highest value of $0.030 \%$, namely PT. Bank Mega Syariah Indonesia Tbk.

The average value of the tax avoidance variable which is proxied by cash effective tax rates (CETR) has an average of 0.37 with a standard deviation of 0.395 . The company with the smallest cash effective tax rates (CETR) is PT. Bank Syariah Bukopin Tbk and PT. BCA Syariah Tbk is equal to 0. The company that has the largest cash effective tax rates (CETR) is PT Bank Syariah Mandiri Tbk, which is 1.89.

\section{Classic assumption test \\ Normality test}

Testing for normality using the Lilliefors test. Provisions in the error test are if the statistic $\mathrm{L}$ count $<\mathrm{L}$ table $(\alpha=0.05)$, then the error data is normally distributed. But if L count $>\mathrm{L}$ table $(\alpha=0.05)$, then the data is not normally distributed. The results of the calculation are as follows:

Table 1.3 Summary of the Normality Test

\begin{tabular}{|c|c|c|c|c|c|c|}
\hline \multirow{2}{*}{ No } & \multirow{2}{*}{ Estimated } & \multirow{2}{*}{$\mathbf{n}$} & \multirow{2}{*}{ count } & \multicolumn{2}{|c|}{ L Tabel } & \multirow{2}{*}{ Decision } \\
\cline { 5 - 6 } & & & $\boldsymbol{\alpha}=\mathbf{0 , 0 5}$ & $\boldsymbol{\alpha}=\mathbf{0 . 0 1}$ & \\
\hline 1 & Y on X1 & 40 & $-0,0351$ & 0,1401 & 0,1630 & Normal \\
\hline 2 & Y on X2 & 40 & $-0,0613$ & 0,1401 & 0,1630 & Normal \\
\hline 3 & Y on X3 & 40 & 0,0079 & 0,1401 & 0,1630 & Normal \\
\hline 4 & Y on X4 & 40 & $-0,0951$ & 0,1401 & 0,1630 & Normal \\
\hline
\end{tabular}

Source: Processed data (2019)

\section{Multicollinearity Test}

The results of the calculation of tolerance according to table 1.4 shows that there are no independent variables that have a tolerance value of less than $10 \%$; all tolerance values are more than $10 \%$; which means there is no correlation between variables. The results of the calculation of the value of the variance inflation factor (VIF) also show the same thing, there are no independent variables that have a VIF value of more than 10; the values of the variance inflation factor (VIF) are all less than 10 . The conclusion is that there is no multicollinearity between independent variables in the regression model based on the tolerance value test. 
Table 1.4 Multicollinearity Test Results

\begin{tabular}{|l|c|c|}
\hline \multirow{2}{*}{ Variabel } & \multicolumn{2}{c|}{ Collinearity Statistics } \\
\cline { 2 - 3 } & Tolerance & VIF \\
\hline Independent Board of Commissioners & 0,750 & 1,334 \\
\hline Audit Committee & 0,762 & 1,313 \\
\hline Audit quality & 0,841 & 1,189 \\
\hline Profitability & 0,870 & 1,150 \\
\hline
\end{tabular}

Source: Processed data (2019)

\section{Autocorrelation Test}

Autocorrelation test is used to determine whether there is a correlation between the error of the intruder in a certain period and the error of the interfering period before. A good regression model is a regression that is free from autocorrelation. Autocorrelation test can be done by Durbin-Watson (DW) testing. The results of the autocorrelation test can be seen in the following table:

Table 1.5 Autocorrelation test results

\begin{tabular}{|c|c|c|c|c|c|}
\hline Model & $\mathbf{R}$ & R Square & $\begin{array}{c}\text { Adjusted R } \\
\text { Square }\end{array}$ & $\begin{array}{c}\text { Std. Error of } \\
\text { the Estimate }\end{array}$ & Durbin-Watson \\
\hline 1 & $0,593^{\mathrm{a}}$ & 0,351 & 0,277 & 0,335 & 2,056 \\
\hline
\end{tabular}

Source: Processed data (2019)

Based on SPSS output, the Durbin Watson statistical value is 2,056. While from the Durbin Watson table with $\mathrm{n}=40$ and $\mathrm{k}=4$, a dtable is obtained (dl (outer boundary) $=1.285$ and du (inner limit) $=1.721$ with a significance level of 5\%,4-du =2,279; and 4-dl =2.715; then from the calculations concluded that the DW-test is located in the test area. This can be seen in the picture as follows:

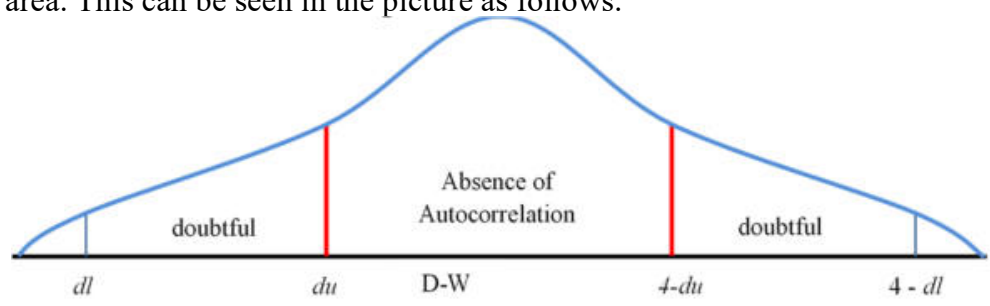

Figure 1.2 Watson Durbin Test

In accordance with the picture above shows that Durbin-Watson is in an area of no autocorrelation. Referring to Ghozali (2011), the regression model in this study is free from the autocorrelation problem because the Durbin Watson values are between du and $4 \mathrm{du}$.

\section{Heteroscedasticity Test}

Detection of heterokedastisitas are: 1) Probability value $>0.05$ means free from heterokedastisitas. 2) Probability value $<0.05$ means that it is exposed to heterokedasticity. The test results using the Spearman rank test can be seen in the following table:

Table 1.6 Heteroscedasticity Test Results

\begin{tabular}{|c|c|c|c|c|c|c|}
\hline & $\mathrm{X} 1$ & $\mathrm{X} 2$ & $\mathrm{X} 3$ & $\mathrm{X} 4$ \\
\hline \multirow[t]{3}{*}{ Spearman's rho } & \multirow{3}{*}{ 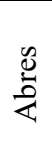 } & $\begin{array}{l}\text { Correlation } \\
\text { Coefficient }\end{array}$ & 0,051 & $-0,154$ & 0,118 & $-0,231$ \\
\hline & & Sig. (2-tailed) & 0,753 & 0,342 & 0,469 & 0,152 \\
\hline & & $\mathrm{N}$ & 40 & 40 & 40 & 40 \\
\hline
\end{tabular}

\section{Source: Processed data (2019)}

Spearman rank test results in the table above shows the significance value of each variable of $0.753,0.342$, 0.469 and 0.152 . Because the significance value of each variable is greater than 0.05 , it can be concluded that the data are free from heterokedasticity.

\section{Regression Analysis Test}

Multiple regression analysis is used to get the regression coefficient which will determine whether the hypothesis made will be accepted or rejected. By using the multiple linear regression method the following results are obtained: 
Table 1.7 Results of regression analysis

\begin{tabular}{|c|c|c|c|c|c|c|c|c|}
\hline \multicolumn{2}{|c|}{ Model } & B & $\mathbf{T}_{\text {count }}$ & Sig & $\mathbf{T}_{\text {tabel }}$ & $\operatorname{adj} \mathbf{R}^{2}$ & $F_{\text {count }}$ & Sig \\
\hline \multirow{5}{*}{1} & (Constant) & 0,483 & & & \multirow{5}{*}{1,688} & \multirow{5}{*}{0,277} & \multirow{5}{*}{4,740} & \multirow{5}{*}{0,004} \\
\hline & $\mathrm{X} 1$ & 0,096 & 0,223 & 0,825 & & & & \\
\hline & $\mathrm{X} 2$ & $-0,195$ & $-0,543$ & 0,590 & & & & \\
\hline & $\mathrm{X} 3$ & 0,331 & 2,680 & 0,011 & & & & \\
\hline & $\mathrm{X} 4$ & 30,096 & $-3,500$ & 0,001 & & & & \\
\hline
\end{tabular}

Source: Processed data (2019)

Based on the results of the regression tests above, an equation can be formed as follows: $\mathrm{Y}=0,483+0,096 \mathrm{X}_{1}$ $-0,195 \mathrm{X}_{2}+0,331 \mathrm{X}_{3}-30,096 \mathrm{X}_{3}+\mathcal{E}$

\section{Determination Coefficient Test $\left(\mathbf{R}^{2}\right)$}

From the table above it is known that the adjusted $\mathrm{R}$ square value is 0.277 . This means that $27.7 \%$ of tax avoidance can be explained by variations in independent variables, namely the independent board of commissioners, audit committee, audit quality and profitability, the remaining $72.3 \%(100 \%-27.7 \%)$ explained by other causes outside the model.

\section{Simultaneous Significance Test (Statistical Test F)}

From the Anova test or the F test in table 1.7 above, the calculated $F$ value is 4.740 with a significance probability that indicates 0.004 . Test probability values are much smaller than $\alpha=0.05$. This shows that together (simultaneously) tax avoidance can be influenced by the independent board of commissioners, audit committee, audit quality and profitability.

\section{Hypothesis testing Relationship of Independent Commissioners with Tax Avoidance}

Based on the calculation results in table 1.7 above, it can be seen that the independent commissioner variable does not affect the tax avoidance in a positive direction, which can be seen from the comparison between the table and $t$ count, ie the table is greater than $t$ count, with a value of 1.688 and $t$ count 0.223 and the level the significance is greater than 0.05 . Thus Hal was rejected.

\section{Relationship of the Audit Committee with Tax Avoidance}

Based on the calculation results in table 1.7 above it can be seen that the audit committee variable does not affect the tax avoidance with a negative direction, which can be seen from the comparison between ttable and tcount, ie ttable is greater than tcount, with a value of 1.688 and tcount -0.543 and the level of the significance is greater than 0.05 . Thus Ha2 rejected.

\section{Relationship of Audit Quality with Tax Avoidance}

Based on the calculation results in table 1.7 above it can be seen that the audit quality variable influences tax avoidance in a positive direction, which can be seen from the comparison between ttable and tcount, ie ttable is smaller than ttest, with a ttable value of 1.688 and ttest 2.680 and its level of significance is more smaller than 0.05. Thus Ha3 received.

\section{Relationship of Profitability with Tax Avoidance}

Based on the calculation results in table 1.7 above it can be seen that the profitability variable affects tax avoidance in a negative direction, which can be seen from the comparison between ttable and tcount, ie ttable is smaller than tcount, with a ttable value of 1.688 and tcount $-3,500$ and a significance level of more smaller than 0.05. Thus Ha4 received.

\section{Discussion \\ Relationship of Independent Commissioners with Tax Avoidance}

From the results of the study note that the independent commissioner variable does not affect the tax avoidance in a positive direction. This shows that the more proportion of independent commissioners owned by the company so that tax avoidance can be minimized. The results of this study are in line with research conducted by Arry (2017) which states that the influence of independent directors on actions to minimize corporate taxes can be explained by the greater number of independent directors, the greater the effect is to supervise management performance. This supervision can reduce agency problems that arise such as the opportunistic attitude of management to bonuses, so that management has an interest in reducing tax payments to maximize bonuses received by management. With greater supervision, management will be careful in making decisions and transparent in running the company so that tax avoidance can be minimized. Actively the independent commissioner can encourage management to comply with applicable tax laws and reduce risks such as low investor confidence. 


\section{Relationship of the Audit Committee with Tax Avoidance}

From the results of the study note that the audit committee variable does not affect the tax avoidance with a negative direction. According to the IDX and Bapepam-LK, each company listed on the IDX must have an audit committee, whose members consist of one independent commissioner as chairman and at least 2 independent company external parties as members. The board of commissioners must establish an audit committee of at least three people who are appointed and dismissed and are responsible for the board of commissioners. Audit committees with few members tend to act more efficiently, but also have weaknesses, namely the lack of member experience. The results of this study support research conducted by Tommy and Maria (2013) and Rahmi (2014) which state that the audit committee has no significant effect on tax avoidance.

\section{Relationship of Audit Quality with Tax Avoidance}

From the results of the study note that audit quality variables affect tax avoidance in a positive direction. This means that the higher audit quality will cause increased tax avoidance. The results of this study are in line with research by Rahmi (2014) and Arry (2017) which states that audit quality has a positive effect on tax avoidance. So the company audited by the big four KAP will indeed be more likely to be trusted by the tax authorities because the KAP has a good reputation, has high integrity, but if the company can provide benefits and better welfare to the KAP that has a good reputation, it could be The KAP was cheating to maximize the welfare of the KAP, as was the case with Enron in 2004 (Fadhilah, 2014).

\section{Relationship of Profitability with Tax Avoidance}

From the results of the study note that the profitability variable has a negative effect on tax avoidance. This means that the lower profitability will cause a decrease in tax avoidance. These results support the research conducted by Kurniasih and Sari (2013). Return on assets is one indicator for companies in achieving corporate profits. Where profit is the most important factor in determining the amount of effective tax rate payment. Then the higher the value of the company's net profit and the higher the profitability so that companies that have high profitability have the opportunity to position themselves in tax palnning which reduces the amount of tax liability burden (Chen, et al, 2010).

\section{Conclusions}

Based on the results of the analysis conclusions can be drawn as follows: 1) the independent commissioner variable does not affect the tax avoidance; 2 ) the audit committee variable has no effect on tax avoidance; 3 ) audit quality variables affect tax avoidance; and 4) profitability variable influences tax avoidance.

\section{Limitation}

There are several limitations encountered in this study, among others: 1) Limited research using independent variables, namely the variable size of the Board of Directors, Board of Commissioners, Independent Commissioners, Sharia Supervisory Board and Company Size; 2) The researcher limits the object of research of Islamic banking companies registered at Bank Indonesia'

\section{Suggestions}

By considering the existing limitations, it is expected that future research will improve the following factors: 1) In the next research, it is better to add several companies from various sectors that will be studied in order to better describe the condition of each company. In addition, adding indicators for the implementation of good corporate governance and financial performance ratios so that they can represent the implementation of good corporate governance in all companies from various sectors in Indonesia; 2) For investors it is recommended that significant variables such as independent commissioners can be used as additional information in the company; 3 ) For the management of Sharia Commercial Banks to comply with all regulations or provisions concerning banks, especially Sharia Commercial Banks that have been made by Bank Indonesia and the Financial Services Authority which began in 2014 as supervisors of banking companies. Especially regulations regarding the number of boards of directors, boards of commissioners, and independent commissioners so that company performance is better so that good corporate governance is realized.

\section{BIBLIOGRAPHY}

Arry Eksandy. (2017). Pengaruh Komisaris Independen, Komite Audit, Dan Kualitas Audit Terhadap Penghindaran Pajak (Tax Avoidance). Competitive, Vol. 1, No. 1

Ayu Annisa Nuralifmida dan Lulus Kurniasih. (2012). Pengaruh Corporate Governance terhadap Tax Avoidance. Jurnal Bisnis dan Manajemen, Vol. 1, No. 1

Christopher S. Armstronga; Jennifer L. Blouina; Alan D. Jagolinzerb; and David F. Larcker. (2015). Corporate governance, incentives, and tax avoidance. Journal of Accounting and Economics. Vol. 60, No. 1

Fitri Damayanti dan Tridahus Susanto. (2015). Pengaruh Komite Audit, Kualitas Audit, Kepemilikan Institusional, Risiko Perusahaan dan Return On Assets Terhadap Tax Avoidance. E S E N S I Jurnal Bisnis dan Manajemen. Vol. 5, No. 2

Ghozali, I. (2013). Aplikasi Analisis Multivariate dengan Program IBM SPSS 22. Semarang: Badan Penerbit Universitas Diponegoro. 
Ghozali, Imam dan Chariri, Anis. (2007). Teori Akuntansi. Badan Penerbit Universitas Diponegoro Semarang.

Hafidz Ridho Ansori dan Safira. (2018). Analisis Pengaruh Manajemen Risiko Terhadap Profitabilitas (Studi Komparatif Pada Bank Umum Konvensional dan Bank Umum Syariah yang Terdaftar di OJK Periode 20122015). Jurnal Profita. Vol. 11. No. 1. April.

I Gusti Ayu Cahya Maharani \& Ketut Alit Suardana. (2014). Pengaruh Corporate Governance, Profitabilitas, dan Karakteristik Eksekutif Pada Tax Avoidance Perusahaan Manufaktur. E-Jurnal Akuntansi Universitas Udayana. Vol. 9, No. 2

Lidia Desiana, Mawardi, dan Sellya Gustiana. (2016). Pengaruh Good Corporate Governance Terhadap Profitabilitas (ROE) Pada Bank Umum Syariah di Indonesia Periode 2010-2015. I-Finance. Vol. 2. No. 2.

Mardiasmo. 2009. Perpajakan Edisi Revisi 2009. Yogyakarta: Penerbit Andi.

Ni Nyoman Dewi Kristiana dan Ketut Jati. (2014). Pengaruh Karakter Eksekutif, Karakteristik Perusahaan dan Dimensi Tata Kelola Perusahaan yang Baik pada Tax Avoidance. E-jurnal Akuntansi Universitas Udayana. Vol. 6, No. 2

Pohan Anwar. (2011). Optimizing Corporate Tax Management, Kajian Perpajakandan Tax Planning Terkini. Edisi I. Jakarta: BumiAksara.

Putu Rista Diantari dan IGK Agung Ulupui. (2016). Pengaruh Komite Audit, Proporsi Komisaris Independen, dan Proporsi Kepemilikan Institusional Terhadap Tax Avoidance. E-Jurnal Akuntansi Universitas Udayana. Vol.16, No. 1

Rahmi Fadhilah. (2014). Pengaruh Good Corporate Governance Terhadap Tax Avoidance (Studi Empiris pada Perusahaan Manufaktur yang Terdaftar di Bursa Efek Indonesia 2009-2011). Jurnal Akuntansi Universitas Negeri Padang. Vol. 2, No. 1

Syeldila \& Niki. (2015). Pengaruh Corporate Governance Terhadap Tax Avoidance: Studi Empiris Pada Perusahaan Manufaktur. JAAI. Vol. 19, No. 2

Tommy Kurniasih \& Maria M. Ratna Sari. (2013). Pengaruh Return On Assets, Leverage, Corporate Governance, Ukuran Perusahaan dan Kompensasi Rugi Fiskal pada Tax Avoidance. BULETIN STUDI EKONOMI. Vol. 18 , No. 1 